Research Article

\title{
Knowledge, Attitude, and Practice of Mothers on the First 1000 Days of Life
}

\author{
Indah S. Widyahening, ${ }^{1 *}$ Muhammad A. Aufa, ${ }^{2}$ Muhammad F. Alhas, ${ }^{2}$ Aji B. Widodo, ${ }^{2}$ Dewi Friska ${ }^{1}$ \\ ${ }^{1}$ Department of Community Medicine, ${ }^{2}$ Undergraduate Medical Student, \\ Faculty of Medicine Universitas Indonesia, Jakarta
}

\author{
*corresponding author: indah_widyahening@ui.ac.id \\ Received 1 December 2020; Accepted 30 August 2021 \\ http://doi.org/10.23886/ejki.9.65.129
}

\begin{abstract}
The first 1000 days of life is the window period which critically determines the children's growth and development and individual's health afterwards. The knowledge, attitude, and practice (KAP) of pregnant mothers and mothers with children under two years old greatly influence the optimum growth and development of children during the period. This study was aimed to evaluate the KAP of mothers about the first 1000 days of life and its associated factors. A cross-sectional study was conducted at a sub-district in Depok city in August 2017. Subjects were purposively recruited to fill the validated KAP questionnaire on the first 1000 days. A total of 110 subjects were recruited, the higher proportion of them have adequate knowledge (42.7\%), good attitude ((62.7\%), and good practice (61.8\%). The mothers' knowledge was associated with attitude and practice $(p<0.001)$ but the attitude and practice were not associated $(p=0.175)$. Maternal education was the only factor that associated with knowledge $(p=0.018)$ and attitude $(p=0.013)$ while family income was associated with practice $(p=0.018)$. This finding strengthened the importance of the existing community empowerment program such as the integrated health post (posyandu) in improving the KAP of mothers to achieve better child's development during the first 1000 days period.
\end{abstract}

Keywords: first 1000 days of life, knowledge, attitude, practice, nutrition

\section{Pengetahuan, Sikap dan Perilaku Ibu mengenai 1000 Hari Pertama Kehidupan}

\begin{abstract}
Abstrak
Seribu hari pertama kehidupan (1000 HPK) adalah periode emas yang sangat menentukan tumbuh kembang anak hingga kesehatan individu pada masa selanjutnya. Pengetahuan, sikap dan perilaku (PSP) ibu hamil dan ibu yang mengasuh anak berusia dua tahun ke bawah sangat menentukan asuhan 1000 HPK yang optimal. Penelitian ini bertujuan untuk mengetahui PSP ibu hamil dan ibu dengan anak berusia di bawah 2 tahun mengenai konsep 1000 HPK serta faktor - faktor yang berhubungan dengan ketiga aspek tersebut. Studi potong lintang dilakukan di Kampung Lio, Depok pada Agustus 2017. Ibu hamil dan ibu dengan anak berusia kurang dari 2 tahun direkrut secara purposif untuk mengisi kuesioner PSP tentang 1000 HPK. Sebanyak 110 subjek direkrut, proporsi terbesar subject memiliki tingkat pengetahuan cukup (42,7\%), sikap sebagian besar baik (62,7\%) dan perilaku sebagian besar juga baik $(61,8 \%)$. Pengetahuan berhubungan dengan sikap dan perilaku $(p<0.001)$ tetapi sikap dan perilaku tidak berhubungan $(p=0,175)$. Tingkat pendidikan ibu adalah faktor yang berhubungan dengan pengetahuan $(p=0,019)$ dan sikap $(p=0,013)$. Tingkat penghasilan keluarga adalah faktor yang berhubungan dengan perilaku $(p=0,018)$ mengenai 1000 HPK. Hasil ini menguatkan pentingnya posyandu sebagai upaya partisipasi masyarakat dalam meningkatkan PSP ibu untuk mencapai perkembangan anak yang optimal pada periode 1000 HPK.

Kata kunci: seribu hari pertama kehidupan, pengetahuan, sikap, perilaku, nutrisi
\end{abstract}




\section{Introduction}

The first 1000 days of life refers to the period of a human life starting from 270 days since the conception, pregnancy until birth and the 730 days of life from birth until two years old. ${ }^{1}$ It is scientifically proven as the most important period (the critical window) of a human being that determine the optimal growth and development of the child and even determine one's health later in adulthood. ${ }^{2}$ One particular concern about the first 1000 days of life is the nutritional status of the pregnant mother and her child later on. The enormous importance of adequate nutritional intake, both macronutrients and micronutrients have been demonstrated in various studies which documented the association between nutritional deficiency and adverse pregnancy outcomes upon the newborn, such as intrauterine growth restriction, prematurity, low birth weight, and various organ defects. 3 Failure to provide adequate nutritional intake, provision of basic immunization as well as the regular examination of the child's growth and development are also the major problem which lead to significant health problem and resulted in stunting, wasting, morbidity and even mortality. ${ }^{3}$

The first 1000 days of life as the golden period and window of opportunity to ensure the optimal growth and development of the children has become the main concern of the government worldwide as well as Indonesia. ${ }^{2}$ A scaling-up nutrition (SUN) movement from world leaders has been adopted by Indonesian government as Gerakan 1000 HPK (National Movement of Nutritional Improvement Acceleration for the First 1000 days of life) since 2010 with various programs for its implementation. 4

In a family scale, pregnant mothers and the mother of children under 2 years are the key population that determine the nutritional status in a person's 1000 days of life. Therefore, all the mothers have to be proficient in knowledge, appropriate in attitude and competent in practice for the 1000 days of life. In that sense, they have sufficient knowledge of its importance and perform all the required practice such as routine antenatal care, routine pregnant iron and folate supplement intake, immediate initiation of breastfeeding, giving an exclusive breastfeeding as well as accessing community-based integrated health post (Pos Pelayanan Terpadu/POSYANDU) for children immunization and routine examination of children's growth and development. The purpose of this study was to evaluate the knowledge, attitude, and practice of mother in Kampung Lio, Depok city, a suburban region at the outskirts of Jakarta which is the target population of community development program of Universitas Indonesia. Furthermore, this study attempts to identify the socio-demographic factors associated with those aspects in order that an appropriate program can be formulated according to the problems and its root causes identified.

\section{Methods}

This was a community-based cross-sectional study involving pregnant mother and the mother who are nurturing their children with the age under two years. The study was conducted at Kampung Lio, Pancoran Mas subdistrict, Depok city, West Java in August 2017. Ethical approval was obtained from the Institutional Review Board of the Faculty of Medicine, Universitas Indonesia (ethical approval letter number 487/UN2.F1.D1/KBK/PDP.01/2017). Sample size was calculated using the sample for prevalence study where prevalence $(p)$ is considered as unknown for this population hence the value is determined as $50 \%$. The sample size calculation resulted in 107 subjects taking into account $10 \%$ of drop out, with $\alpha=0.05$ and $90 \%$ of power. Subjects were consecutively recruited from the community by means of door-to-door visit by the researchers. Women at any age who were pregnant or having a child with the age of under two years were invited to join a short interview using the prepared list of questions for knowledge measurement. Subjects were then interviewed guided by a questionnaire.

The study utilized a list of 16 multiple choice questions about the 1000 days of life for the evaluation of maternal knowledge. Besides, a validated questionnaire measuring attitude and practice upon the first 1000 days of life was used, there were 18 questions for each aspect of attitude and practice. Each question item was a five-point Likert scale ranging from strongly disagree disagree - doubtful - agree - and strongly agree that represents the subjects' view as well as representation of their daily practice. For multiple choice questions of knowledge, each question was valued 1 for correct answer and 0 for false answer. For the assessment of attitude and practice, a selffilled questionnaire each comprised of 18 questions were used. In that questionnaire, for each positive question, a value of 1 was given for strongly disagree answer and progressively increased to 5 for strongly agree option. Meanwhile, for a negative question, a score of 5 was given for a strongly disagree answer while decreases accordingly until a score of 1 for strongly agree answer. For every measure of primary outcome, the total score of 70 or above was classified as good level, a score range 
of 55 - 70 was categorized as fair/adequate level, while a total score of less than 55 was classified as inadequate. Parity was classified as nullipara (first pregnancy), primipara (mother having one child), and multipara (mother having two or more children). The questionnaire had been validated by means of pilot study involving 30 subjects appropriate for the inclusion criteria but not included in the analysis. All the point questions in the questionnaire were shown to be valid with the r value exceeded 0.361 in Pearson Correlation test. Besides, all the questions were also shown to be reliable as the CronbachAlpha value for all questions were above 0.7.

The primary outcomes of this study were the mothers' level of knowledge, attitude and practice about the first 1000 days of life. The secondary outcomes were the socio-demographic profile of the subjects, namely maternal age, education level, family's monthly income, maternal social activity, access towards healthcare facility, as well as health insurance possession. The mothers' age was confirmed by ID-card checking was then classified into three categories; young $(<20$ years old), ideal maternal age ( $21-35$ years old) and older age for mothers $>35$ years old. Education level was classified as low [elementary school (6 years of education) until junior high school (9 years of education)], middle (senior high school/ vocational high school- 12 years of education), and high (diploma/undergraduate level). Types of family structure were classified as nuclear family which comprised of married partners and their offspring and extended family which include at least three generations: grandparents, married offspring, and grandchildren. The mothers' ethnicity was identified from the birthplace as written in the ID card and was confirmed through interview. Family income was the net income from all members of family which was classified as low-income (less than 1.5 million rupiah/month or USD 107.7), middle income (ranging from 1.5 million to 3 million/month or USD 107.7 - 215.4) and high income (more than $3 \mathrm{million} / \mathrm{month}$ ). The distance from nearest healthcare facility was classified as near if the distance from home was less than 3 kilometers $/ 1.86$ miles or far if the distance was longer than it. The possession of healthcare insurance was whether the mother was listed as national health insurance card bearer (either the insurance monthly premium was paid by the government or they pay it by themselves regardless of the class of insurance) or they possessed private health insurance. The mother participation in social activity was whether they actively participate in religious, social, or health event including the POSYANDU activities. The possible association between the sociodemographic factors of the mother and their knowledge, attitude and practice on the first 1000 days of life were evaluated through Chi-square analysis. The statistical analysis was conducted using SPSS for Windows version 20.

\section{Results}

A total of 110 subjects were recruited, 5 subjects were primigravida, 23 were primipara, and the remaining 82 subjects were multipara. As shown in the table 1 , most of the subjects' age were $21-35$ years with education level of senior high school and were housewife (un-employed). The family structure of the mothers living in are mostly nuclear family. Betawi and Javanese ethnics were the dominant ethnic group. Most of the mothers' economic status were middle to lower income with active participation in social activity, especially in monthly gatherings for community-based integrated health post (POSYANDU) organized by local primary health center (Pusat Kesehatan Masyarakat/ PUSKESMAS) health personnel and helped by local cadres. The POSYANDU activities are ante natal care, as well as baby/children anthropometric measurement, vitamin and vaccine administration. Most of the subjects use primary health center as their healthcare facility which is located nearby; $39.1 \%$ subjects had not owned any health insurance.

The primary outcome of the study was presented in the table 2 . In terms of knowledge about the first 1000 days of life, most of subjects had adequate level of knowledge. The levels of knowledge were sufficient and moderate but considered not good enough. Later on, when identified through peritem questions, most subjects' knowledge was lacking on the meaning of the first 1000 days of life and the benefit of exclusive breastfeeding. The other lacking knowledge were about practical matters such as the number of antenatal care visits during pregnancy and the number of iron tablet supplements that need to be consumed during pregnancy. Only a minor proportion of subjects had inadequate level of knowledge while less than half proportion of the subjects had good level of knowledge.

From the attitude aspects, good level of attitude was the predominant proportion and slightly less proportion were fair/sufficient. None of the subjects were categorized as having inadequate level of attitude towards the first 1000 days of life. 
Table 1. Characteristics of the mothers

\begin{tabular}{|c|c|}
\hline Characteristics & $\mathrm{n}(\%)$ \\
\hline \multicolumn{2}{|l|}{ Age (years) } \\
\hline$\leq 20$ & $11(10.0)$ \\
\hline $21-35$ & $74(67.3)$ \\
\hline$\geq 35$ & $25(22.7)$ \\
\hline \multicolumn{2}{|l|}{ Education level } \\
\hline Elementary school to junior high school & $41(37.3)$ \\
\hline Senior High school & $61(55.4)$ \\
\hline Bachelor & $8(7.3)$ \\
\hline \multicolumn{2}{|l|}{ Occupation status } \\
\hline working & $11(10)$ \\
\hline housewife & $99(90)$ \\
\hline \multicolumn{2}{|l|}{ Parity } \\
\hline First pregnancy & $5(4.5)$ \\
\hline Having 1 child & $23(20.9)$ \\
\hline Having 2 children & $38(34.6)$ \\
\hline Having more than 2 children & $44(40)$ \\
\hline \multicolumn{2}{|l|}{ Family type } \\
\hline Nuclear family & $90(81.8)$ \\
\hline Extended family & $20(18.2)$ \\
\hline \multicolumn{2}{|l|}{ Ethnicity } \\
\hline Javanese & $37(33.6)$ \\
\hline Sundanese & $26(23.6)$ \\
\hline Betawi & $41(37.30$ \\
\hline Other ethnics & $6(5.5)$ \\
\hline \multicolumn{2}{|l|}{ Family income, monthly } \\
\hline Less than Rp1,500,000 & $19(17,6)$ \\
\hline$R p 1,500,000$ to $R p 3,000,000$ & $52(48.1)$ \\
\hline More than $\mathrm{Rp} 3,000,000$ & $37(34.3)$ \\
\hline \multicolumn{2}{|l|}{ Participation in the social activity } \\
\hline Active & $65(59.1)$ \\
\hline Not participating & $45(40.9)$ \\
\hline \multicolumn{2}{|l|}{ Health facility ever accessed } \\
\hline Hospital & $7(5.5)$ \\
\hline Primary health center & $63(49.2)$ \\
\hline POSYANDU & $5(3.9)$ \\
\hline 24-hour clinic & $33(25.8)$ \\
\hline Private doctor/midwife or other health personnel & $20(15.6)$ \\
\hline \multicolumn{2}{|l|}{ Health insurance bearings } \\
\hline BPJS/KIS & $67(60.9)$ \\
\hline Not having any insurance & $43(39.1)$ \\
\hline \multicolumn{2}{|l|}{$\begin{array}{l}\text { The distance between the house and } \\
\text { nearby health facility }\end{array}$} \\
\hline Distant & $15(13.6)$ \\
\hline Near & $95(86.4)$ \\
\hline
\end{tabular}


The primary outcome of the study was presented in the table 2. In terms of knowledge about the first 1000 days of life, most of subjects had adequate level of knowledge. The levels of knowledge were sufficient and moderate but considered not good enough. Later on, when identified through per item questions, most subjects' knowledge was lacking on the meaning of the first 1000 days of life and the benefit of exclusive breastfeeding. The other lacking knowledge were about practical matters such as the number of antenatal care visits during pregnancy and the number of iron tablet supplements that need to be consumed during pregnancy. Only a minor proportion of subjects had inadequate level of knowledge while less than half proportion of the subjects had good level of knowledge.

From the attitude aspects, good level of attitude was the predominant proportion and slightly less proportion were fair/sufficient. None of the subjects were categorized as having inadequate level of attitude towards the first 1000 days of life.

Table 2. The Level of Knowledge, Attitude, and Practice of Mothers about The First 1000 Days of Life

\begin{tabular}{lccc}
\hline \multicolumn{1}{c}{ Characteristics } & $\mathbf{n}(\%)$ & $\begin{array}{c}\text { Attitude } \\
\text { p-value }\end{array}$ & $\begin{array}{c}\text { Practice } \\
\text { p-value }\end{array}$ \\
\hline $\begin{array}{l}\text { Knowledge } \\
\text { Inadequate }\end{array}$ & $24(21.8)$ & & \\
Adequate & $47(42.7)$ & $<0.001$ & $<0.001$ \\
Good & $39(35.5)$ & & \\
Attitude & & - & 0.175 \\
Fair & $41(37.3)$ & & - \\
good & $69(62.7)$ & & - \\
Practice & & & \\
Fair & $42(38.2)$ & & \\
Good & $68(61.8)$ & & \\
\hline
\end{tabular}

Comparative analysis on the sociodemographic characteristics of the mothers and the knowledge, attitude, and practice towards the first 1000 days were presented in the table 3 . Only a minor number of characteristics were found to be associated with any of the three primary outcomes. The knowledge of the mother about the first 1000 days of life was associated only with their education level which is significantly higher among mothers with bachelor education level compared to elementary school - high school. The mothers' attitude also associated only with their education level. Meanwhile, the practice on the first 1000 days of life was associated only with the level of family income. None of the three outcomes were associated with maternal age, occupation status, parity, family form, ethnicity, participation on social activity, health insurance possession, nor the distance of health facility from home. 
Table 3. Factors Associated with The Level of Knowledge Attitude, and Practice of Mothers on The First 1000 Days of Life

\begin{tabular}{|c|c|c|c|}
\hline Characteristics & $\begin{array}{c}\text { Knowledge, } \\
\text { p-value }\end{array}$ & $\begin{array}{l}\text { Attitude, } \\
\text { p-value }\end{array}$ & $\begin{array}{c}\text { Practice, } \\
\text { p-value }\end{array}$ \\
\hline \multicolumn{4}{|l|}{ Age (years) } \\
\hline$<35$ & 0.694 & 0.311 & 0.246 \\
\hline \multicolumn{4}{|l|}{$\geq 35$} \\
\hline \multicolumn{4}{|l|}{ Education level } \\
\hline Elementary school to senior high school & $0.019^{*}$ & $0.013^{*}$ & 0.888 \\
\hline \multicolumn{4}{|l|}{ Bachelor } \\
\hline \multicolumn{4}{|l|}{ Occupation status } \\
\hline working & 0.916 & 0.292 & 0.700 \\
\hline \multicolumn{4}{|l|}{ Household mother } \\
\hline \multicolumn{4}{|l|}{ Parity } \\
\hline Pregnant or having 1 child & 0.533 & 0.462 & 0.577 \\
\hline \multicolumn{4}{|l|}{ Having 2 children } \\
\hline \multicolumn{4}{|l|}{ Having more than 2 children } \\
\hline \multicolumn{4}{|l|}{ Family form } \\
\hline Core family & 0.604 & 0.78 & 0.405 \\
\hline \multicolumn{4}{|l|}{ Main family } \\
\hline \multicolumn{4}{|l|}{ Ethnicity } \\
\hline Javanese & 0.644 & 0.885 & 0.520 \\
\hline \multicolumn{4}{|l|}{ Sundanese } \\
\hline \multicolumn{4}{|l|}{ Betawi } \\
\hline \multicolumn{4}{|l|}{ Family income, monthly } \\
\hline $\mathrm{Rp} 1,500,000$ to $\mathrm{Rp} 3,000,000$ & 0.396 & 0.175 & $0.018^{\star}$ \\
\hline \multicolumn{4}{|l|}{ More than $\mathrm{Rp} 3,000,000$} \\
\hline \multicolumn{4}{|l|}{ Participation in the social activity } \\
\hline Active & 0.705 & 0.196 & 0.054 \\
\hline \multicolumn{4}{|l|}{ Not participating } \\
\hline \multicolumn{4}{|l|}{ Health insurance bearings } \\
\hline $\mathrm{JKN} / \mathrm{KIS}^{+}$ & 0.416 & 0.425 & 0.065 \\
\hline \multicolumn{4}{|l|}{ Not having any insurance } \\
\hline \multicolumn{4}{|c|}{ The distance between the house and nearby health facility } \\
\hline Distant & 0.887 & 0.734 & 0.194 \\
\hline Near & & & \\
\hline
\end{tabular}

*Indicates statistical significance

\section{Discussion}

This cross-sectional study conducted in a middle to lower socioeconomic community at the southern part of the Greater Jakarta region assessed the knowledge, attitude, and practice of the pregnant mothers and mothers with children under two years about the first 1000 days of life. This study found out that those subjects had adequate level of knowledge as well as good level of attitude and practice towards the first 1000 days of life. Given the characteristics of the study subjects who were mostly in middle to lower level on socioeconomic status, education level of the mothers was the only factor which associated with the knowledge and the attitude of them upon the first 1000 days of life. Meanwhile, family income was the only significantly associated factors with the practice of the mothers on the first 1000 days of the children.

Compared to the findings of similar studies conducted in the other region, this communitybased study resulted in similar pattern with the other health facility-based study. A study in Makassar city 
involving primigravida women with the education level mostly high school and bachelor degree found that their knowledge and attitude about the first 1000 days of life were adequate and very good, respectively. In terms of knowledge, $50 \%$ of subjects were categorized as good and $43.2 \%$ were very good. For the attitude $56.8 \%$ were categorized as very good and the rest were good.5 Another study in Sleman, Yogyakarta region involving pregnant women with very similar characteristics in terms of education level and socioeconomic status also showed that their knowledge about the concept and programs of the first 1000 days of life were mostly adequate $(42.5 \%){ }^{6}$

Nutrition is the primary concern of the first 1000 days of life and several studies had assessed the knowledge, attitude, and perception of pregnant women about nutritional status. A study in a single $\mathrm{PHC}$ in Bandung by Widyastuti et $\mathrm{al}^{7}$ revealed that the proportion of subjects with good knowledge, good attitude, and good nutritional status were $32.0 \%, 52.0 \%$, and $82.6 \%$ out of 75 pregnant women, respectively. This study found a statistically significant association between knowledge and attitude upon nutritional status $(p=0.02)$ but no association between knowledge and the subjects' nutritional status $(p=0.66)$. Study conducted in the other district of Depok city by Setyaningsih et $\mathrm{al}^{8}$ involving mother with infants and toddler under 59 months showed that the predominant level of knowledge was sufficient $(75.9 \%)$, sufficient/ fair attitude $(57.1 \%)$, and good practice $(71.4 \%)$ in nutritional fulfillment of the children's nutrition. Another study in a single antenatal care clinic at Uttar Pradesh, India utilizing a 25 points questionnaire showed that only $22 \%$ pregnant women had good knowledge about nutrition in pregnancy while 36\% subjects were lacking in knowledge. ${ }^{9}$

This study found a significant association between level of knowledge on the first 1000 days of life with the attitude and practice but no association between attitude and practice. In this study, maternal education level was the only factor that associated with knowledge and attitude upon the first 1000 days of life. Meanwhile, family income was the only factor associated with the mothers' practice. Mothers with higher level of education (high school or bachelor degree) were shown to have higher proportion of good level of knowledge as well as good attitude compared to mothers with lower level of education. The higher the family income, the higher also the proportion of mothers with good practice on the first 1000 days of life. In a study by Sanyogita et al10, education status and parity were two factors which associated with the knowledge of pregnant women nutrition (of the need to take additional nutritional intake during pregnancy). Education level association with knowledge and practice were coherent with the health belief model in which demographic variables influence the perceived susceptibility, perceived benefits, and perceived barriers as well as health motivation.11 Economic - health practice association may be attributed to several aspects that requires additional spending such as daily food source diversification, iron and folate supplement and routine antenatal care visits. Antenatal care visits in which iron and folate supplement were provided are free of charge for the health insurance bearers if it is conducted at public primary health center, but a large proportion of subjects in this study had not owned the insurance although the national government had established the target that all Indonesian citizen must have the universal health insurance by the end of 2019. Even when the health insurance is available, some factors still hinder pregnant women from attending antenatal visits, such as the distance of health facility from home, lack of time due to daily routine, lack of the understanding on the importance for antenatal visits and so on. The other variable response of practice on the first 1000 days of life were some activities that are uncommon for mothers with lower economic status such as pregnant aerobics class and social activities.

There were several limitations of this study. The categorization for the level of knowledge, attitude, and practice was somewhat arbitrary hence hindered practical interpretation. The crosssectional design is also not the strongest design to establish causation. Nonetheless, this study provides a quick portrait of the situation related to the implementation of First 1000 days movement. Future studies which addressed the challenges faced by the mothers regarding the fulfillment of important practices in the first 1000 days of life and identification of the available resources within the family and at the community for the optimization of first 1000 days of life will complement this study to provide a more complete picture.

\section{Conclusion}

Pregnant mothers and the mothers nurturing children under 2 years in an urban area of West Java overall had adequate/sufficient level of knowledge as well as good level of attitude 
and practice towards the first 1000 days of life. Existing community empowerment program such as POSYANDU still needs to specifically address their activity towards the improvement of KAP of mothers to achieve optimal results in the first 1000 days period of the children.

\section{Acknowledgment}

No conflict of interest was declared. The authors would like to thank Kampung Lio community leaders for their support during the subjects' recruitment. We also would like to acknowledge the assistance of Septian I. Prasetya during the manuscript development.

\section{References}

1. Moore T, Arefadib N, Deery A, West S. The first thousand days: an evidence paper [internet]. Melbourne; Centre for Community Child Health Murdoch Children's Research Institute;2017. Available from: www.rch.org.au/ccch

2. Cusick $S$ and Georgieff MK [Internet]. The first 1,000 days of life: The brain's window of opportunity [internet]. 2014. Available from: https://www.unicef-irc. org/article/958-the-first-1000-days-of-life-the-brainswindow-of-opportunity.html

3. Tang M, Dewey KG, Krebs NF. Nutritional requirements in the life stages. In: Karakochuk CD, Whitfield KC, Green TJ, Kraemer K, editors. The biology of the first 1,000 days. 1st ed. Florida: CRC Press; 2017.p.3-75.

4. Kementerian Koordinator Bidang Kesejahteraan Rakyat. Kerangka Kebijakan Gerakan Nasional Percepatan Perbaikan Gizi dalam Rangka Seribu Hari Pertama Kehidupan (Gerakan 1000 HPK) [internet]. Indonesia; 2013 p. 71. Available from: https://www. bappenas.go.id/files/7713/8848/0483/KERANGKA_ KEBIJAKAN_-_10_Sept_2013.pdf. Indonesian.
5. Bustan ANH. Gambaran pengetahuan dan sikap ibu hamil primigravida tentang program 1000 hari pertama kehidupan bayi di rumah sakit ibu dan anak siti fatimah makassar [Internet]. Makassar; 2016. Available from: http://repositori.uin-alauddin.ac.id/8140/1/ANDI NOVIA HANDAYANI BUSTAN.pdf. Indonesian.

6. Dewi DAK. Gambaran pengetahuan ibu hamil tentang program 1000 hari pertama kehidupan di puskesmas Mlati II Sleman Yogyakarta [Skripsi]. Program studi kebidanan (D-3) Sekolah Tinggi IImu Kesehatan Jenderal Achmad Yani Yogyakarta; 2017. Indonesian.

7. Widiastuti W, Mutyara K, Siddiq A. Knowledge, attitude and nutritional status in pregnant women. Althea Med J. 2015;2:231-4.

8. Setyaningsih SR, Agustini N. Pengetahuan, sikap, dan perilaku ibu dalam pemenuhan gizi balita: sebuah survai. J Keperawatan Indones. 2014;17:88-94. Indonesian.

9. Gupta R, Agarwal S, Singh N, Jain R, Katiyar A, Siddiqui A. A study to assess knowledge and attitude of antenatal women about maternal nutrition attending a tertiary care centre. Int J Reprod Contracept Obstet Gynecol. 2016;5:1549-52.

10. Sanyogita, Singh T, Deepti SS. Knowledge, attitude, practice and determining factors regarding nutrition during pregnancy among females of rural Punjab. Int J Community Med Public Heal. 2019;6:2874.

11. Champion VL, Skinner CS. The health belief model. In: Glanz K, Rimer BK, Viswanath K, editors. Health behavior and health education. 4th ed. San Francisco: Jossey-Bass; 2008. p.45-62. 